\title{
Integrated Management of Downy Mildew of Yellow Sarson
}

\author{
Sunil Kumar ${ }^{1}$, R. B. Singh ${ }^{2}$ and R. C. Shakywar ${ }^{3 *}$ \\ ${ }^{1}$ AICRP on Soybean, School of Agricultural Sciences and Rural Development, Nagaland University, Medziphema, \\ Nagaland (797 106), India \\ ${ }^{2}$ Dept. of Plant Pathology, Narendra Deva University of Agriculture and Technology, Kumarganj, Faizabad, \\ Uttar Pradesh (224 229), India \\ ${ }^{3}$ Dept. of Plant Protection, College of Horticulture and Forestry, Central Agricultural University, Pasighat, \\ Arunachal Pradeash (791 102), India
}

Article History

Manuscript No. AR1325

Received in $1^{\text {st }}$ March, 2015

Received in revised form $24^{\text {th }}$ January, 2016

Accepted in final form $7^{\text {th }}$ February, 2016

\section{Correspondence to}

*E-mail: rcshakywar@gmail.com

\section{Keywords}

Yellow sarson, downy mildew, integrated management, Perenospora parasitica

\begin{abstract}
An experiment was conducted at Student's Instructional Farm of Narendra Deva University of Agriculture and Technology, Kumarganj, Faizabad to find out the integrated management of downy mildew. Yellow sarson varieties/entries under test showed variable downy mildew disease response for both the years. NDYS 2018, showed least susceptibility followed by NDYS 132-2 during 2006-07, while in 200708, NDYS 115-1 proved most susceptible followed by NDYS 2 . In general highest disease intensity was recorded in $20^{\text {th }}$ October sown crop as compared to $30^{\text {th }}$ and $10^{\text {th }}$ November sown crop during both the years. Second date of sowing ( $30^{\text {th }}$ October) showed lower downy mildew intensity of 26.98 and $29.77 \%$ during $2006-07$ and 2007-08, respectively. However, higher test weight and seed yield (3.75 and $3.70 \mathrm{~g}$ and 1385.73 and $\left.1356.98 \mathrm{~kg} \mathrm{ha}^{-1}\right)$ were noted in first date of sowing i.e., $20^{\text {th }}$ October in respective years. In respect of varieties, YST 151 showed lower downy mildew intensity of 27.59 and $30.26 \%$ and higher test weight of 3.75 and $3.68 \mathrm{~g}$ and seed yield of 1391.88 and $1363.07 \mathrm{~kg} \mathrm{ha}^{-1}$ as compared to NDYS 2. Companion $0.15 \%$ was found most effective in reducing the disease severity and enhancing the test weight and seed yield during the years of testing followed by Mancozeb $0.2 \%$. Maximum downy mildew intensity and minimum test weight and seed yield were noted in control plot.
\end{abstract}

\section{Introduction}

Rapeseed-mustard are the most important oilseeds crops of India belonging to family Brassicaceae which play an important role in Indian economy. These crops suffer from a number of devastating diseases such as Alternaria blight, downy mildew, white rust and powdery mildew etc. Out of them downy mildew caused by Peronospora parasitica (Pers.) (de Bary) is one of the most important disease cause up to $47 \%$ yield losses (Bains and Jhooty, 1980). This disease is known to occur in all the rapeseed mustard growing areas in the mid-eastern part of India. There is urgent need to work on integrated management of downy mildew of yellow sarson, though it is particularly susceptible to downy mildew disease (Kolte, 1985; Singh and Singh, 2005b) and has higher oil content. Therefore, study were undertaken to investigate the integrated management of downy mildew of yellow sarson (Brassica campestris L. var. yellow sarson Prain) to minimize the disease severity and enhancing the seed yield.

\section{Materials and Methods}

A trial consisting of 10 yellow sarson varieties/entries namely YST 151, NDYS 2, NDYS 117, NDYS 123, NDYS 2018, NDYS 116-1, NDYS 107, NDYS 119, NDYS $115-$ 1 and NDYS 132-2 were planted in randomized block design with replication on 20 October, 30 October and 10 November during 2006-07 and 2007-08 crop seasons at Student's Instructional Farm of Narendra Deva University of Agriculture and Technology Kumarganj, Faizabad to record data. Severity of downy mildew was measured on cotyledons and leaves following 0-5 point scale (Natti et al., 1967). Whereas, $0=$ cotyledons leaves ${ }^{-1}$ free from infection; $1=$ small creamy white to light brown spots on cotyledons leaves $^{-1}$ covering $1-10 \%$ area; $2=$ small creamy white to light brown spots with cottony growth on lower surface covering $10.1-25 \%$ cotyledons leaves ${ }^{-1}$ area; $3=$ creamy white to 
light brown spots with cottony growth covering $25.1-50 \%$ cotyledons leaves ${ }^{-1}$ area; $4=$ creamy white to light brown spots with cottony growth covering $50.1-75 \%$ cotyledons leaves ${ }^{-1}$ area and $5=$ creamy white to light brown spots with cottony growth covering $>75 \%$ cotyledons leaves ${ }^{-1}$ area. Ten plants in each plot were selected randomly and tagged. Downy mildew severity was measured visually as per cent affected cotyledons leaves ${ }^{-1}$ area on lower, middle and upper leaves. A separate trial was conducted for the management of downy mildew. Two varieties YST 151 and NDYS 2 were sown on 20 and 30 October during both the years. Efficacy of four fungicides namely Mancozeb, Companion (carbendazim $12 \%+$ mancozeb $63 \%$ ), Propiconazole and Iprobenfos were tested for the management of downy mildew at both the date of sowing.

\section{Results and Discussion}

Initial symptoms of downy mildew was recorded as early as on $1^{\text {st }}$ and $3^{\text {rd }}$ November on the cotyledons of NDYS 115-
1 attaining highest per cent disease intensity (PDI) of 83.48 and $85.85 \%$ on 18 and 21 November, respectively for the year 2006-07 and 2007-08 in 20 October sown crops. In $30^{\text {th }}$ October sown crop the disease initiated on 18 and 19 November attaining highest PDI of 76.80 and $77.95 \%$, respectively during both the years, while in $10^{\text {th }}$ November sown crop the initiation of disease was noted on 29 November and 01 December attaining highest PDI of 70.85 and $73.90 \%$ on 18 and 21 December, respectively for the first and second year on the same entry i.e. NDYS 115-1 (Table 1). Latest disease initiation was noted on 07 November on cotyledons of NDYS 2018 attaining PDI of 20.13 and $21.27 \%$ on 28 and 29 November in 20 October sown crop during 2006-07 and 2007-08, respectively. In 30 October sown crop, the disease was initiated 23 and 24 November attaining highest PDI of 18.50 and $18.80 \%$ on 13 and 17 December during both the years, while in 10 November sown crop its initial symptoms could be noted on 02 and 04 December attaining PDI of 14.90 and $16.20 \%$ on 26 and 29 December during both the

\begin{tabular}{|c|c|c|c|c|c|c|c|c|c|}
\hline \multirow{3}{*}{$\begin{array}{l}\text { Entries } \\
\text { 2006-07 }\end{array}$} & \multicolumn{3}{|c|}{ Date of initiation (DAS) } & \multicolumn{3}{|c|}{$\begin{array}{l}\text { Days to highest disease intensity } \\
\text { from the date of initiation }\end{array}$} & \multicolumn{3}{|c|}{ Highest disease intensity (\%) } \\
\hline & $\mathrm{D}_{1}$ & $\mathrm{D}_{2}$ & $\mathrm{D}_{3}$ & $\mathrm{D}_{1}$ & $\mathrm{D}_{2}$ & $\mathrm{D}_{3}$ & $\mathrm{D}_{1}$ & $\mathrm{D}_{2}$ & $\mathrm{D}_{3}$ \\
\hline & & & & & & \\
\hline YST 151 & 15 & 21 & 21 & 18 & 20 & 22 & 68.37 & 64.80 & 59.50 \\
\hline NDYS 2 & 14 & 20 & 20 & 19 & 21 & 22 & 72.98 & 68.95 & 64.75 \\
\hline NDYS 117 & 14 & 21 & 20 & 19 & 20 & 21 & 61.82 & 57.92 & 54.92 \\
\hline NDYS 123 & 14 & 22 & 21 & 20 & 20 & 22 & 58.95 & 55.02 & 46.82 \\
\hline NDYS 2018 & 18 & 24 & 22 & 21 & 22 & 24 & 20.13 & 18.50 & 14.90 \\
\hline NDYS 116-1 & 12 & 19 & 19 & 17 & 18 & 20 & 79.83 & 75.05 & 70.75 \\
\hline NDYS 107 & 14 & 23 & 21 & 19 & 20 & 22 & 56.74 & 51.70 & 51.80 \\
\hline NDYS 119 & 15 & 21 & 20 & 19 & 20 & 22 & 62.67 & 59.10 & 52.67 \\
\hline NDYS 115-1 & 12 & 19 & 19 & 17 & 19 & 19 & 83.48 & 76.80 & 70.85 \\
\hline NDYS $132-2$ & 15 & 22 & 20 & 20 & 21 & 22 & 53.12 & 50.37 & 47.60 \\
\hline \multicolumn{10}{|l|}{ 2007-08 } \\
\hline YST 151 & 16 & 22 & 23 & 20 & 21 & 22 & 71.75 & 65.35 & 61.90 \\
\hline NDYS 2 & 14 & 20 & 21 & 19 & 21 & 22 & 76.32 & 71.32 & 66.50 \\
\hline NDYS 117 & 14 & 21 & 21 & 21 & 22 & 23 & 63.40 & 58.35 & 55.85 \\
\hline NDYS 123 & 14 & 21 & 23 & 22 & 23 & 22 & 60.80 & 55.65 & 47.42 \\
\hline NDYS 2018 & 18 & 24 & 24 & 22 & 23 & 25 & 21.27 & 18.80 & 16.20 \\
\hline NDYS 116-1 & 14 & 19 & 20 & 19 & 20 & 22 & 83.85 & 75.80 & 69.85 \\
\hline NDYS 107 & 15 & 22 & 23 & 20 & 21 & 23 & 59.70 & 55.75 & 51.75 \\
\hline NDYS 119 & 16 & 21 & 21 & 20 & 22 & 23 & 64.70 & 60.15 & 55.54 \\
\hline NDYS $115-1$ & 14 & 19 & 21 & 18 & 19 & 20 & 85.85 & 77.95 & 73.90 \\
\hline NDYS $132-2$ & 15 & 22 & 22 & 20 & 20 & 23 & 55.85 & 50.75 & 50.38 \\
\hline
\end{tabular}

$\mathrm{D}_{1}: 20.10 .06$ and $07 ; \mathrm{D}_{2}: 30.10 .06$ and $07 ; \mathrm{D}_{3}: 10.11 .06$ and 07 ; DAS: Days after sowing 
respective years on the same entry.

In general, the disease was initiated 12 to 18 days after sowing (DAS) in 2006-07 and 14 to 18 DAS in 2007-08, and highest per cent disease intensity was attained after 17 to 21 days and 18 to 22 days of its initiation during both the years, respectively on 20 October sown crop. In $30^{\text {th }}$ October sown crop its initiation was noted after 19 to 24 days of sowing in both the years and highest PDI was noted after 18 to 22 days of its initiation in first year and 19 to 23 days in second year. However, in 10 November sown crop the initiation was noted after 19 to 22 days of sowing during 2006-07 and 21 to 24 DAS during 2007-08 and highest PDI was observed after 19 to 24 days and 20 to 25 days of its initiation, respectively, during both the years of testing. As the date of sowing delayed, days of initiation after sowing and days to highest disease intensity from the date of initiation increased but highest per cent disease intensity decreased. Concurrent with present findings different workers have also reported that infection of downy mildew on cotyledons started by the end of October and progress up to November and crop planted after midNovember escaped downy mildew infection (Mehta, 1993; Saharan et al., 1997; Singh and Singh, 2005a). Singh and Bhajan (2006) have also reported the earliest infection of downy mildew on 12 October attaining highest PDI on 02 December in 1999 and as late as on 25 November attaining highest PDI on 10 December in 2003. They also reported that early sowing is more prone to downy mildew infection on cotyledons leaves $^{-1}$ than late sown crop in mid-eastern India.

Lowest downy mildew intensity of $26.98 \%$ after last spray in the second date $\left(30^{\text {th }}\right.$ October $)$ of sowing found significantly superior to first date of sowing having $29.66 \%$ during the first year, while during second year disease severity was at par in both the date of sowing (Table 2). YST 151 yellow sarson showed lower downy mildew intensity of $27.59 \%$. It proved significantly superior to NDYS 2 that showed higher downy mildew intensity of $29.06 \%$ during first year. During second year it was found non-significant. Test weight and seed yield was recorded significantly higher in "NDYS 2" during both the years.

All the spray fungicides significantly reduced the severity of downy mildew disease intensity and increased the test weight and seed yield during both the years in comparison to unsprayed check (Table 2). Amongst all the fungicides tested, companion (carbendazim 12\%+mancozeb 63\%)@ $0.15 \%$ was found significantly more effective in managing the downy mildew disease of $15.88 \%$ and enhancing the test weight of $4.00 \mathrm{~g}$ and seed yield of $1465.21 \mathrm{~kg} \mathrm{ha}^{-1}$ followed by mancozeb@0.2\% and iprobenfos@0.075\%, respectively during both the years (Table 2). Companion (carbendazim 12\%+mancozeb 63\%)@0.15\% was noted most effective against the downy mildew disease followed by mancozeb $(0.2 \%)$ and iprobenfos. Companion (carbendazim $12 \%+$ mancozeb $63 \%$ ) was used for the first time against the downy mildew disease in case of yellow sarson and found effective. Chauhan and Muheet (1976); Mathur and Bhatnagar (1988); Puzari and Saikia (1997) also reported the effective management of this disease by spraying the different fungicides such as Difolatan $80 \mathrm{WP}$, Riomil MZ, Benlate, Apron 35 SD.

Table 2: Effect of date of sowing, varieties and fungicides on downy mildew intensity, test weight and seed yield of yellow sarson varieties

\begin{tabular}{|c|c|c|c|c|c|c|}
\hline \multirow[t]{2}{*}{ Treatments } & \multicolumn{2}{|c|}{ Per cent disease intensity } & \multicolumn{2}{|c|}{ Test weight $(\mathrm{g})$} & \multicolumn{2}{|c|}{ Yield $\left(\mathrm{kg} \mathrm{ha}^{-1}\right)$} \\
\hline & 2006-07 & $2007-08$ & 2006-07 & $2007-08$ & 2006-07 & $2007-08$ \\
\hline \multicolumn{7}{|l|}{ Date of sowing } \\
\hline $20^{\text {th }}$ October & $\begin{array}{c}29.66 \\
(32.76)\end{array}$ & $\begin{array}{c}31.93 \\
(33.54)\end{array}$ & 3.75 & 3.70 & 1385.73 & 1356.98 \\
\hline $30^{\text {th }}$ October & $\begin{array}{c}26.98 \\
(30.92)\end{array}$ & $\begin{array}{c}29.77 \\
(32.77)\end{array}$ & 3.66 & 3.58 & 1282.00 & 1252.58 \\
\hline $\mathrm{SEm} \pm$ & 0.12 & 0.41 & 0.013 & 0.007 & 31.66 & 20.83 \\
\hline $\mathrm{CD}(p=0.05)$ & 0.55 & 1.80 & 0.054 & 0.030 & 89.83 & 62.50 \\
\hline \multicolumn{7}{|l|}{ Varieties } \\
\hline YST 151 & $\begin{array}{c}27.59 \\
(31.36)\end{array}$ & $\begin{array}{c}30.26 \\
(33.12)\end{array}$ & 3.74 & 3.68 & 1391.88 & 1363.07 \\
\hline NDYS 2 & $\begin{array}{c}29.06 \\
(32.33)\end{array}$ & $\begin{array}{c}31.43 \\
(33.20)\end{array}$ & 3.68 & 3.60 & 1275.25 & 1246.50 \\
\hline $\mathrm{SEm} \pm$ & 0.11 & 0.53 & 0.007 & 0.008 & 35.83 & 32.00 \\
\hline $\mathrm{CD}(p=0.05)$ & 0.33 & 1.47 & 0.020 & 0.022 & 99.16 & 95.33 \\
\hline
\end{tabular}




\begin{tabular}{|c|c|c|c|c|c|c|}
\hline \multirow[t]{2}{*}{ Treatments } & \multicolumn{2}{|c|}{ Per cent disease intensity } & \multicolumn{2}{|c|}{ Test weight $(\mathrm{g})$} & \multicolumn{2}{|c|}{ Yield $\left(\mathrm{kg} \mathrm{ha}^{-1}\right)$} \\
\hline & 2006-07 & $2007-08$ & 2006-07 & $2007-08$ & 2006-07 & $2007-08$ \\
\hline \multicolumn{7}{|l|}{ Fungicides } \\
\hline Mancozeb@0.2\% & $\begin{array}{c}23.02 \\
(28.65)\end{array}$ & $\begin{array}{c}17.93 \\
(25.02)\end{array}$ & 3.95 & 3.88 & 1397.08 & 1366.67 \\
\hline Companion@0.15\% & $\begin{array}{c}15.88 \\
(23.43)\end{array}$ & $\begin{array}{c}12.23 \\
(19.46)\end{array}$ & 4.00 & 3.90 & 1465.21 & 1433.33 \\
\hline Propiconazole@0.075\% & $\begin{array}{c}32.86 \\
(34.91)\end{array}$ & $\begin{array}{c}26.95 \\
(31.73)\end{array}$ & 3.64 & 3.78 & 1328.33 & 1318.54 \\
\hline Iprobenfos@0.075\% & $\begin{array}{c}27.70 \\
(31.74)\end{array}$ & $\begin{array}{c}22.00 \\
(27.94)\end{array}$ & 3.78 & 3.84 & 1391.58 & 1363.92 \\
\hline Unsprayed & $\begin{array}{c}42.60 \\
(40.48)\end{array}$ & $\begin{array}{c}35.11 \\
(36.72)\end{array}$ & 3.17 & 3.11 & 1085.62 & 1061.46 \\
\hline $\mathrm{SEm} \pm$ & 0.30 & 0.29 & 0.017 & 0.018 & 61.67 & 57.50 \\
\hline $\mathrm{CD}(p=0.05)$ & 0.98 & 0.95 & 0.049 & 0.058 & 201.11 & 187.52 \\
\hline
\end{tabular}

Figures in parentheses are angular transform value

\section{Conclusion}

Downy mildew was recorded as early as in first week of November on cotyledons of NDYS 115-1 attaining highest disease intensity in third week of November during both the year in $20^{\text {th }}$ October sown crop. Disease intensity was decreased with delayed sowing during both the years. Companion@0.15\% was found effective in managing disease intensity and enhancing the test weight and seed yield followed by mancozeb@0.2\% during both the years.

\section{References}

Bains, S.S., Jhooty, J.S., 1980. Mixed infection of Albugo candida and Peronospora parasitica on Brassica juncea inflorescence and their control. Indian Phytopath, 32(2), 268-271.

Chauhan, L.S., Muheet, A., 1976. Control of downy mildew of rapeseed and mustard. Pesticides 10(5), 38-39.

Kolte, S.J., (1985). Diseases of Annual Edible oilseeds crop. Rapeseed-Mustard and Sesame diseases. CRC Press. Inc. Boca Raton, Florida, 135.

Mathur, S., Bhatnagar, M.K., 1988. Effective chemical control of white rust and downy mildew disease of mustard. Indian Phytopathology 41(2), 185-188.
Mehta, N., (1993). Epidemiology of white rust and downy mildew disease complex in mustard and residual toxicity of fungi toxicant. Ph.D. Thesis, C.C.S. Haryana Agriculture conversely, Hisar, Haryana, India, 154.

Natti, J.J., Dickson, M.H., Atkin, J.D., 1967. Resistance of Brassica oleracea varieties to downy mildew. Phytopathology 57, 144-147.

Puzari, K.C., Saikia, U.N., 1997. Efficacy of fungicides for controlling downy mildew of rapeseed. Indian Phytopathology 50(4), 520-523.

Saharan, G.S., Verma, P.R., Nashaat, N.I., 1997. Monograph on Downy mildew of crucifers. Saskatoon Research Centre Technical Bulletin 1997-01, Research Branch Agricultural and Agri-Food Canadians 76-88.

Singh, R.B., Bhajan, R., 2006. Status on downy mildew, Pernospora parasitica and genetic variability for resistance in yellow sarson, Brassica campestris var. yellow sarson. Journal of Oilseeds Research 23(2), 361-362.

Singh, R.B., Singh, R.N., 2005a. Status and management of foliar diseases of timely sown mustard in mid-eastern India. Plant Disease Research 20(1), 18-24.

Singh, R.B., Singh, R.N., 2005b. Fungicidal management of foliar diseases of mustard in mid-eastern India. Indian Phytopathology 58(1), 51-56. 